Y1lmaz, M. \& Kadan, Ö. F. (2019). An Action Research Aiming to Reveal the Effects of Paired Reading on Eliminating Reading Difficulties. Bartin University Journal of Faculty of Education, 8(1), 231-244.

Bartın University Journal of Faculty of Education, 8(1), 231-244

Bartın Üniversitesi Eğitim Fakültesi Dergisi, 8(1), 231-244

buefad.bartin.edu.tr

\title{
An Action Research Aiming to Reveal the Effects of Paired Reading on Eliminating Reading Difficulties
}

\author{
Muamber YILMAZ*a ${ }^{*}$ Ömer Faruk KADAN ${ }^{\mathrm{b}}$
}

\begin{tabular}{l} 
Article Info \\
\hline DOI: 10.14686/buefad.432501 \\
\hline Article History: \\
Received 09.06.2018 \\
Accepted 26.12.2018 \\
Published 01.02.2019 \\
\hline Keywords: \\
Reading, \\
Reading Difficulty, \\
Paired Reading Method \\
\hline Article Type: \\
Research article \\
\end{tabular}

\begin{abstract}
The effects of paired reading on developing reading skill of a student who had difficulty in reading were researched in the study. The study designed as an action research was carried out with one 5th grader having reading difficulty and studying at Bartın Gazi Secondary School in the second term of 2016-2017 academic year. First, the student was asked to read two informative reading texts - Trash (Çöpler) and Recycling (Geri Dönüşüm) - in the 5th grade Turkish coursebook , and his reading was recorded in order to determine his reading level. His reading level was scored based on the error analysis inventory. It was found that his reading level was at anxiety level. Next, the student was asked to read an informative text entitled "Traveler Turtle is in Denizli (Gezgin Kaplumbağa Denizli'de)" in the 4th grade Turkish coursebook. It was seen that the student was still at anxiety level. Then, he was asked to read an informative text entitled "Traffic Rules (Trafik Kuralları)" in the 3 rd grade Turkish course book. The instruction period was 30 hours in total -5 hours a week. At the end of the reading instruction period, the student was asked to read a text entitled "Domestic Goods (Yerli Mal1)" selected from the 3rd grade Turkish course book. It was revealed that the student's reading level reached independent level.
\end{abstract}

\section{Okuma Güçlüklerini Gidermede Eşli Okuma Yönteminin Etkisine Yönelik Bir Eylem Araştırması}

\begin{tabular}{|c|c|}
\hline \multicolumn{2}{|c|}{ Makale Bilgisi } \\
\hline DOI: 1 & 586/buefad.432501 \\
\hline $\begin{array}{l}\text { Makale } \\
\text { Geliş } \\
\text { Kabul } \\
\text { Yayın }\end{array}$ & $\begin{array}{l}\text { mişi: } \\
09.06 .2018 \\
26.12 .2018 \\
01.02 .2019\end{array}$ \\
\hline $\begin{array}{l}\text { Anahta } \\
\text { Okuma } \\
\text { Okuma } \\
\text { Eşli Or } \\
\text { Makale } \\
\text { Araştır }\end{array}$ & $\begin{array}{l}\text { limeler: } \\
\text { lüğü, } \\
\text { Yöntemi, } \\
\ddot{u}: \\
\text { Iakalesi }\end{array}$ \\
\hline
\end{tabular}

\section{Öz}

Bu çalışmada, okuma güçlüğü çeken bir öğrencinin okuma becerisini geliştirmede eşli okuma yönteminin etkisi araştırılmış̧ır. Eylem araştırması deseni kullanılan bu çalışma, 2016-2017 eğitim öğretim yılı ikinci döneminde Bartın Gazi Ortaokulu 5. sinıftan seçilen ve okuma güçlüğ̈u yaşayan bir öğrenciyle yürütülmüştür. Öğrencinin okuma düzeyini belirlemek için 5. sınıf Türkçe ders kitabından "Çöpler ve Geri Dönüşüm” adlı bilgilendirici metin okutulmuş ve öğrencinin okuması kaydedilmiştir. Öğrencinin okuma düzeyi hata analiz envanterine göre puanlandırılmıştır. Öğrencinin okuma seviyesinin endişe düzeyinde olduğu tespit edilmiştir. Ardından 4. sınıf Türkçe ders kitabından "Gezgin Kaplumbağa Denizli’de" adlı bilgilendirici türde metin okutulmuştur. Öğrencinin okuma seviyesinin yine endişe düzeyinde olduğu belirlenmiştir. Daha sonra öğrenciye 3. sınıf Türkçe ders kitabından "Trafik Kuralları" adlı bilgilendirici metin okutulmuştur. Öğrencinin okuma güçlüklerini gidermek için 3. sınıf Türkçe ders kitabından seçilen hikâye türü metinlerle eşli okuma yöntemi kullanılarak okuma eğitimi yapılmıştır. Okuma eğitimi haftada 5 saat olmak üzere toplam 30 saat devam etmiştir. Okuma eğitiminin sonunda öğrenciye 3. sınıf Türkçe ders kitabından seçilen "Yerli Malı" isimli metin okutulmuştur. Öğrencinin okuma seviyesinin serbest düzeye çıtı̆̆ 1 tespit edilmiştir.

\footnotetext{
*Corresponding Author: muammeryilmaz66@gmail.com

a Assoc. Prof. Dr. Bartın University, Facultiy of Education, Bartın/Turkey, https://orcid.org/0000-0003-1736-7717

b Lect. Mustafa Kemal University, Foreign Language School, Hatay/Turkey, https://orcid.org/0000-0001-5187-3694
} 


\section{Introduction}

Reading is a lifelong process. It is an indispensable need that we face in all phases of our lives. Individuals encounter a great deal of information that requires reading in their lives. They encounter reading in public institutions, in shopping centers, in hospitals, in subways, in airports, in traffic, in finding an address, in reading newspaper, in watching TV; in short, in all phases of life. In such cases, it must be quite difficult to keep up with life for the individuals who are illiterate.

Reading can be described as an individual's process of obtaining meaning from the texts as a result of putting symbols having been received through sense organs to a mental process by applying his/her prior knowledge (Yılmaz, 2018). According to Smith and Dechant (1977) reading is a process of interpretation of a written text. Two things are needed for pre-mentioned interpretation: recognition and perception. Recognition is about recognizing letters and words, and it is a sensorial activity. Recognition activity is followed by perception of the materials in the mind. This material is organized, interpreted and linked up with prior knowledge (as cited in Dökmen, 1994).

Reading is a learning area which is frequently applied for getting information by people. In this case, individuals need to comprehend his/her reading thoroughly and accurately. In other words, individuals should understand what he/she reads. That is because of the fact that he/she enjoys only if he/she understands what is read. A boring reading will not become a pattern, and it will not be more than an annoying activity.

Reading comprehension can be described as an individual's gaining new knowledge by relating new knowledge he/she gets in the text with his/her prior knowledge. Word recognition skill lies on the basis of reading (Yllmaz, 2018). Readers whose word recognition skills are poor do not have enough time for reading comprehension since they spend their care and energy on word articulation. That kind of readers make reading mistakes very often, read slowly and cannot understand most of their reading (Y1lmaz, 2008). They also experience reading difficulty. Additionally, they do not like reading; they fail in the exams and classes. Finally, they are frequently introvert and they feel themselves unaided.

The reason of a student's not recognizing the words stems from the fact that he/she cannot diagnose the words in advance and cannot make use of the context. First, the teacher should know which words the student, whose word recognition skill is poor, does not know in order to help him/her. To be able to do this, the teacher needs to identify the words which are difficult to read by dealing with the student individually (Kee, 1958). According to May (1986), the readers who have poor reading skills focus their attention on word recognition. They are not aware of the main idea of the text. They get busy with word articulation rather than its meaning. On the other hand, the readers whose reading skills are developed are active, they know how to infer from their reading and they can enlarge meaning of the text (Salinger, 2003).

From $15 \%$ to $20 \%$ of the primary school students in the world have difficulty in improving their readingwriting skills. There are some factors causing reading difficulty. These are factors such as the students' familial problems, inadequacy of materials in their houses, their lack of motivation, and mental deficiency (Lyon, Gray, Kavanagh and Krasnegor, 1993; as cited in Joshi, Dahlgren and Gooden, 2002). Oral reading skills should be overemphasized to determine reading levels of primary school students. That is because of the fact that oral reading is a diagnosis tool for a teacher in determining reading level of the children. Yllmaz (2011) gathered oral reading errors of the children in seven categories which are skipping, insertion, reversal, mispronunciation, repetition, misreading and hesitation.

Making a lot of oral reading errors hinders the children's reading comprehension. If the children do not comprehend their reading, they do not feel pleasure of their reading and cannot develop a reading habit. Reading difficulties that the children experience affect their success in other classes in a negative way. These children need to receive individual reading instruction to overcome their reading difficulties. One of the methods applied to resolve reading difficulties is paired reading method.

\section{Paired Reading Method}

Paired reading is a reading activity that is carried out by a reader who has reading difficulty with the help of a better reader (teacher, adult or peer) (Topping, 1998). The text should be read loudly together with the child in paired reading. The aider should adjust his/her reading rate according to the child. In some parts of the text, the child should be allowed to read independently if he/she asks. However, if the child gets difficulty in reading, the aider should take reading over again. The child should be given positive feedback, and should be encouraged to read. The text having been read should be discussed with the child. 
Morgan (1986), stressed that paired reading may be done in houses, schools, libraries and in any other suitable settings. He also suggested that paired reading can be applied based on a daily or weekly program to improve reading skill. Implementing Process of Paired Reading Method:

1. Reading should be started with the person with whom reading will be done in an appropriate setting.

2. If reading is done together, the adult reads the text out loud sentence by sentence while the child repeats with a low tone of voice. If reading is done independently, the aider follows the child, and guides him/her with hand gestures when intervention is needed.

3. The adult tries to prevent reading mistakes of the reader by making him/her read again the parts where he/she makes mistakes during reading.

4. The partner who makes reading done motivates the reader during the paired reading process.

5. If the child reads independently, the adult helps him/her (child, student, etc.) for the words he/she skips, or hesitates.

6. The reader is rewarded with stickers, badges or other gifts to promote his/her reading. Thus, paired reading process is completed (Aytan, 2015).

White (2014) divided paired reading method into three categories which are pre-reading, while reading and post-reading.

Things to be done during pre-reading:

$\checkmark$ A book suitable for the level of the readers should be chosen,

$\checkmark \quad$ The book chosen should be suspenseful and easy to read.

Things to be done while reading:

$\checkmark$ The text should be read out loud by the child and the aider,

$\checkmark$ Reading should be fluent,

$\checkmark$ Connection between the text and real life should be provided,

Things to be done during post-reading:

$\checkmark$ The text should be discussed with the child,

$\checkmark \quad$ The reading should be corroborated with follow-up questions.

It was emphasized that paired reading method contributes to readers' accurate word recognition, improves their reading rates, helps them feel confident, stimulates their reading, makes them careful about spelling while reading and helps them enjoy their reading (Zutell and Rasinski, 1991). In addition to this, Koskinen and Blum (1986) claimed that there was an improvement in word perception, reading fluency and reading comprehension levels of the students in the classes where paired reading had been applied.

When the studies related to reading difficulties were scrutinized, it was concluded that there are a lot of children, especially primary school students, having reading difficulties in our country. Reading difficulties of those children should be treated in order to help them gain a reading habit. Today, teachers at schools are not the ones conveying information; on the contrary, they are the ones leading students to reach information on their own. With this new understanding the students are expected to explore, make conclusions as a result of their researches, relate their prior knowledge and new knowledge, and to be individuals who reach an effective final conclusion. It is a prerequisite for a student to have reading fluency and reading comprehension skills in order to carry out such kinds of skills. That is why impact of paired reading method on overcoming reading difficulties was questioned in this research.

\section{Aim of the Study}

Aim of the research was to reveal the impact of paired reading method on improving reading skill of a $5^{\text {th }}$ grader having reading difficulty. Answers to the following questions were looked for to reach this general aim:

1. What are the reading levels of $5^{\text {th }}$ graders?

2. What is the impact of paired reading method on improving reading levels of the $5^{\text {th }}$ graders?

\section{Method}

\section{Model of the Study}

Action research - a qualitative research design - was employed in the study. Action research is applied by a person who is individually in implementation process such as a manager at a school, a teacher, an education expert or an engineer, a director, a planner, a human resources specialist working at other types of institutions. It is a research approach, in which the implementer carries out the research himself or together with a researcher. 
Moreover, it is an approach in which problems related to implementation process are revealed or in which data collection and analysis towards understanding and solving already revealed problems are applied (Yıldırım and Şimşek, 2005).

\section{Subject Selection Procedure}

The research was implemented on a $5^{\text {th }}$ grade student studying at Bartın Gazi Secondary School. Before selecting the subject, $5^{\text {th }}$ grade teachers were asked if they had any students having reading difficulty. Four $5^{\text {th }}$ graders who were observed to have reading difficulties were identified. The researcher asked these students to read some texts suitable for their class levels, and he tried to determine their reading levels. One student among these students was selected by the researcher as suitable for the purpose of the study.

\section{Data Collection Tools}

$3^{\text {rd }}, 4^{\text {th }}$ and $5^{\text {th }}$ grade Turkish language course books certified by the Head Council of Education and Morality of Ministry of National Education were used as data collection instruments. The implementation with paired reading method was carried out using 30 narrative texts chosen from the $3^{\text {rd }}$ grade Turkish language course book. Additionally, the student was given 30 tale books to read as homework. Inventory of error analysis was employed for the evaluation of the data. This inventory was adapted to Turkish by Y1lmaz (2006). The inventory consists of 3 sections which are setting scale, articulation scale and question scale. Assessment criteria for the inventory of error analysis are as follows:

\section{Inventory of Error Analysis}

a) Criteria for Setting Scale

Did not read at all $=0$ point

The teacher said the word $=1$ point

Did not included the same words and structures $=2$ points

Included the same words and structures $=3$ points

Included the same words and structures; the words used were the same with the writer's expression $=4$ points

Corrected himself $=5$ points

\section{b) Criteria for Articulation Scale}

No letter similarity with the word he used $=0$ point

One letter similarity with the word he used $=1$ point

Two letters similarity with the word he used $=2$ points

$\mathrm{N}$ letter similarity with the word he used $=\mathrm{N}$ point

\section{c) Criteria for Question Scale}

For Simple Comprehension Questions;

Questions not answered at all $=0$ point

Questions partly answered $=1$ point

Questions fully answered $=2$ points

For Deeply Understanding Questions;

Questions not answered at all $=0$ point

Questions partly answered = 1 point

Questions answered almost truly but deficiently $=2$ points

Questions fully answered $=3$ points (Y1lmaz, 2006).

Three different reading levels are identified with the inventory of error analysis. These are as follows;

a) Frustration level: Individuals at this level make several reading errors, and they understand only a small part of their reading. If the total score received from articulation, setting and question scales is below 180, the student is at the frustration level.

b) Instructional level: It means that individuals at this level need help from a teacher or an adult for reading and understanding the text in a required way. If the total score received from articulation, setting and question scales is 180 or above, the student is at the instructional level. Top score for this level is 239.

c) Independent level: Individuals at this level can read and understand the materials suitable for their levels without needing any help from a teacher or an adult. If the total score received from articulation, setting and question scales is 240 or above, the student is at the independent level (Y1lmaz, 2006).

\section{Data Collection}

First, the student was asked to read an informative text, "Trash and Recycling (Çöpler ve Geri Dönüşüm)", in the $5^{\text {th }}$ grade Turkish language course book in order to determine his level of word recognition and understanding. His level of word recognition and understanding was analyzed according to "Inventory of Error 
Analysis", and his reading level was found at the frustration level. Afterwards, the student was asked to read an informative text, "Traveler Turtle is in Denizli (Gezgin Kaplumbağa Denizli'de)", in the $4^{\text {th }}$ grade Turkish language course book. Likewise, after reading level of the student was determined via "Inventory of Error Analysis", his level was found to be at the frustration level. Then, the student was asked to read an informative text, "Traffic Rules (Trafik Kurallar1)", in the $3^{\text {rd }}$ grade Turkish language course book, and his word recognition and understanding level was determined via "Inventory of Error Analysis", and his reading level was found at the instructional level. The implementation with paired reading method was decided to be done with the texts chosen from $3^{\text {rd }}$ grade course book.

The implementation was carried out individually in vice-principal's room. The implementation lasted for 30 hours in total, as 5 hours (one hour a day) per week. Six questions, three of which were simple comprehension questions and three of which were deep understanding questions, about each text were asked to the student. At the end of the reading instruction, the student was asked to read a text, "Domestic Goods (Yerli Mali)", chosen from the $3^{\text {rd }}$ grade Turkish language course book. Assessment texts have been selected informative text type for precisely determine the reading level of students.

\section{Data Analysis}

The inventory of error analysis was employed for data analysis. The student's reading was audiorecorded. The records were analyzed using the inventory of error analysis. Furthermore, 6 reading comprehension questions about each text were asked.

\section{Findings}

\section{The Student's Reading Level Before Implementation}

Reading level of the student was determined before implementation of paired reading method. His reading was recorded, and his reading level was identified with questions asked about the texts read. The student was asked to read the texts - "Trash and Recycling (Çöpler ve Geri Dönüşüm)", "Traveler Turtle is in Denizli (Gezgin Kaplumbağa Denizli'de)" and "Traffic Rules (Trafik Kurallar1)" - in the $5^{\text {th }}$ grade, $4^{\text {th }}$ grade and $3^{\text {rd }}$ grade Turkish language course books respectively. The findings obtained related to the student's reading level were shown in tables.

Table 1. The Student's $5^{\text {th }}$ Grade Reading Level Before Implementation

\begin{tabular}{ll} 
Name of the Text & Trash and Recycling (Çöpler ve Geri Dönüşüm ) \\
Text Type & Information Text \\
Class Level of the Text & $5^{\text {th }}$ Grade \\
Number of Words in the Text & 385 \\
Number of Words Misread & 105 \\
Reading Level & $\begin{array}{l}\text { Setting Scale }+ \text { Articulation Scale }+ \text { Question } \\
\text { Scale }=46+79+46=171 \text { points= Frustration Level }\end{array}$ \\
\hline
\end{tabular}

When Table 1 was analyzed, it was concluded that the student made 105 oral reading errors while reading a text consisting of 385 words, and his reading level was at the frustration level (171 points).

Table 2. The Student's $4^{\text {th }}$ Grade Reading Level Before Implementation

\begin{tabular}{ll} 
Name of the Text & $\begin{array}{l}\text { Traveler Turtle is in Denizli (Gezgin Kaplumbağa } \\
\text { Denizli'de ) } \\
\text { Text Type }\end{array}$ \\
$\begin{array}{ll}\text { Information Text } \\
\text { Class Level of the Text }\end{array}$ & $4^{\text {th }}$ Grade \\
Number of Words in the Text & 263 \\
Number of Words Misread & 84 \\
Reading Level & $\begin{array}{l}\text { Setting Scale + Articulation Scale + Question Scale } \\
=50+81+46=177 \text { points= Frustration Level }\end{array}$ \\
\hline
\end{tabular}


In Table 2, it can be seen that the student made 84 oral reading errors while reading a text consisting of 263 words, and his reading level was at the frustration level (177 points).

Table 3. The Student's $3^{\text {rd }}$ Grade Reading Level Before Implementation

\begin{tabular}{ll}
\hline Name of the Text & Traffic Rules (Trafik Kuralları ) \\
Text Type & Information Text \\
Class Level of the Text & $3^{\text {rd }}$ Grade \\
Number of Words in the Text & 134 \\
Number of Words Misread & 42 \\
Reading Level & $\begin{array}{l}\text { Setting Scale }+ \text { Articulation Scale + Question } \\
\text { Scale }=62+72+56=190 \text { points }=\text { Instructional } \\
\text { Level }\end{array}$ \\
\hline
\end{tabular}

When Table 3 was studied, it was revealed that the student made 42 oral reading errors while reading a text consisting of 134 words, and his reading level was at the instructional level (190 points).

\section{The Student's Reading Level Following Implementation}

At the end of the implementation the student was asked to read a text - "Domestic Goods (Yerli Malı )" chosen from the $3^{\text {rd }}$ grade Turkish language course book. The findings obtained were presented in Table 4 .

Table 4. The Student's $3^{\text {rd }}$ Grade Reading Level Following Implementation

\begin{tabular}{ll}
\hline Name of the Text & Domestic Goods (Yerli Malı ) \\
Text Type & Information Text \\
Class Level of the Text & $3^{\text {rd }}$ Grade \\
Number of Words in the Text & 168 \\
Number of Words Misread & 19 \\
Reading Level & $\begin{array}{l}\text { Setting Scale }+ \text { Articulation Scale + Question Scale } \\
=78+90+73=241 \text { points= Independent Level }\end{array}$ \\
\hline
\end{tabular}

Table 4 showed that the student made 19 oral reading errors while reading a text consisting of 168 words, and his reading level was at the independent level (241 points).

\section{Discussion and Conclusion}

As a result of the study, paired reading method was found effective on decreasing secondary school $5^{\text {th }}$ graders' oral reading mistakes and on increasing their reading levels. This result shows similarities with the results revealed in the previous researches. Eldredge and Quinn (1988), Akyol and Kodan (2016), Yamaç (2013), Fidan and Akyol (2011), İşler and Şahin (2016), Ellis (2009) also concluded that paired reading reduced oral reading mistakes, and it improved reading comprehension skills in their studies. Paired reading method is repetition of a text sentence by sentence by an individual having reading difficulty and by an instructor. From this aspect, repeating a fact underlies in paired reading. This repetition continues until the individual can read fluently. Hence, it can be suggested that repeated reading are effective on eliminating reading difficulties. Researches implemented about this matter support this idea. Y1lmaz and Köksal (2008), Y1lmaz (2009), Y1lmaz (2010), Samuels, (1979), Herman, (1985), Rashotte and Torgesen, (1985), Dowhower, (1987), Sindelar, Monda and O'Shea, (1990), Young, Bower and MacKinnon, (1996) stated in their studies that repeated reading method improved reading and reading comprehension skills of the children having reading difficulties. Thereby, it can be claimed that reading difficulties can be recovered by repeating words and sentences accurately. That is because of the fact that both in paired 
reading method and in other methods applied for treating reading difficulties, the instructor repeats the words or sentences to the individuals having reading difficulties. 


\title{
Okuma Güçlüklerini Gidermede Eşli Okuma Yönteminin Etkisine Yönelik Bir Eylem Araştırması
}

\author{
Giriş
}

Okuma hayat boyu devam eden bir süreçtir. Hayatın her kademesinde karşımıza çıkan okuma faaliyeti vazgeçilmez bir ihtiyaçtır. Bireyler yaşamlarında okuma gerektiren birçok bilgiyle karşılaşırlar. Devlet dairelerinde, alış-veriş merkezlerinde, trafikte, adres bulmada, gazete okumada, televizyon izlemede, hastanede, metroda, hava alanında, kısaca hayatın her kademesinde okumayla karşı karşıya kalırlar. Bu durumda okuma bilmeyen bireyler için yaşama ayak uydurmak çok zor olsa gerek.

Okuma, bireyin ön bilgisini kullanarak duyu organları aracılığıyla aldığı sembolleri zihinsel bir işleme tabi tutması sonucunda metinlerden anlam kurması şeklinde tanımlanabilir (Yılmaz, 2018). Smith ve Dechant'a göre okuma, yazılı bir metnin yorumlanması sürecidir. Söz konusu yorumlamada iki şeye ihtiyaç vardır: Tanıma ve algılama. Tanıma; harflerin, kelimelerin tanınması olup, duyusal bir etkinliktir. Tanıma etkinliğini materyalin beyinde algılanması izler. Algılama sırasında bu materyal hem örgütlenir, anlamlandırılır, hem de bunların eski bilgilerle bağlantısı kurulur (Akt.: Dökmen, 1994).

Okumak, insanın hayatı boyunca bilgi edinmede sıkça kullandığı bir öğrenme alanıdır. Bu durumda birey okuduklarını eksiksiz ve doğru bir şekilde anlamaya ihtiyaç duymaktadır. Bir başka ifadeyle bireyin okuduğunu anlaması gerekmektedir. Çünkü birey okuduğunu anladığı sürece okuma ona keyif verir. Keyif vermeyen bir okuma, alışkanlık haline dönüşemeyeceği gibi, birey için can sıkıcı bir aktivite olmaktan öteye gidemez.

Okuduğunu anlama; bireyin okuduğu metinde karşılaştığı yeni bilgilerle eski bilgiler arasında ilişki kurması sonucunda yeni bir öğrenmeye ulaşması olarak tanımlanabilir. Okumanın temelinde kelime tanıma becerisi yer almaktadır (Yılmaz, 2018). Kelime tanıma becerisi gelişmemiş okuyucular dikkat ve enerjilerini kelimeyi seslendirme işine ayırdıklarından okuduklarını anlamaya vakitleri pek kalmaz. Bu tür okuyucular okuma sırasında sıkça okuma hatası yaparlar, yavaş okurlar ve okuduklarının çoğunu anlayamazlar (Yılmaz, 2008). Bu tür okuyucular okuma güçlüğü yaşarlar. Okumayı sevmezler, sınavlarda ve derslerde başarısızdırlar, çoğunlukla içine kapanıktırlar, kendilerini yardımsız hissederler.

Öğrencinin kelime tanıyamamasının nedeni, önceden kelimeyi önceden teşhis edememesinden ve cümlenin gelişinden faydalanamamasından kaynaklanmaktadır. Kelime tanıma becerisi gelişmemiş öğrenciye yardım etmek için öğretmenin ilk önce öğrencinin hangi kelimeleri tanımadığını bilmesi gerekir. Bunun için öğrenciyle birebir ilgilenerek öğrencinin hangi kelimeleri okumada güçlük çektiğini belirlemesi gerekir (Kee, 1958). May’e göre (1986) okuma becerileri gelişmemiş okuyucular, dikkatlerini kelimeyi tanıma üzerinde yoğunlaştırırlar. Metnin ana fikrinin farkında değildirler. Anlamadan ziyade, kelimeleri sese çevirmekle meşgul olurlar. Bunun yanında (Salinger, 2003) okuma becerisi gelişmiş okuyucular aktiftirler, okuduklarından nasıl anlam çıkarılacağını bilirler ve metinin anlamını genişletebilirler.

İlköğretim çocuklarının yaklaşık olarak \%15 ila \%20'si okuma-yazma becerilerini ilerletmede güçlük yaşamaktadırlar. Okuma güçlüklerine bir takım faktörler neden olmaktadır. Bunlar; öğrencilerin ailevi sorunları, evde okumayla ilgili materyallerinin yetersizliği, öğrencilerin motivasyon eksikliği, zekâ geriliği gibi faktörlerdir (Lyon, Gray, Kavanagh ve Krasnegor, 1993; akt.: Joshi, Dahlgren ve Gooden, 2002). İlköğretim çağındaki çocukların okuma seviyelerinin belirlenmesi için sesli okuma becerileri üzerinde durulmalıdır. Çünkü sesli okuma çocuğun okuma seviyesi konusunda öğretmene dönüt sağlayan bir teşhis aracıdır. Yılmaz (2011) çocukların yaptıkları sesli okuma hatalarını 7 sınıfta toplamıştır. Bunlar: Atlama, ekleme, ters çevirme, telaffuz, tekrar, yanlış okuma ve duraklama hatasidir.

Sesli okuma hatalarının fazlaca yapılması çocuğun okuduğu metni anlamasını güçleştirmektedir. Okuduğunu anlayamayan çocuk, okumaktan haz duymayacak ve okuma alışkanlığı geliştiremeyecektir. Öğrencilerin yaşadıkları okuma güçlükleri onların diğer derslerdeki başarılarına olumsuz olarak yansımaktadır. $\mathrm{Bu}$ öğrencilerin okuma güçlüklerinin giderilmesi için bireysel okuma eğitimi almaları gerekmektedir. Okuma güçlüklerinin tedavisinde kullanılan yöntemlerden birisi de eşli okuma yöntemidir.

\section{Eşli Okuma Yöntemi}

Eşli okuma; okuma güçlüğüne sahip okuyucunun, kendisinden daha iyi okuma yapabilen bir kişinin (Öğretmen, yetişkin, akran) yardımıyla yapılan okumadır (Topping, 1998). Eşli okumada metin çocukla birlikte sesli olarak okunmalıdır. Yardımcı, okuma hızını çocuğun okuma hızına göre ayarlamalıdır. Metnin bazı noktalarında çocuk bireysel olarak okumak isterse buna izin verilmelidir. Ancak çocuğun okumada zorlanması halinde okuma işi tekrar yardımcı kişi tarafından devralınmalıdır. Çocuğa olumlu dönütler verilmeli ve okumaya karşı desteklenmelidir. Okunan metin çocukla birlikte tartışılmalıdır. 
Morgan (1986), eşli okumanın; evde, okulda, kütüphanede ve uygun ortamlarda yapılabileceğini vurgulamaktadır. Okuma becerisinin geliştirilmesi için günlük veya haftalık olarak hazırlanan bir programla eşli okumanın gerçekleştirilebileceğini ifade etmektedir.

Eşli Okuma Yöntemini Uygulama Süreci:

1. Eşli okuma için uygun bir ortamda okuma yapılacak kişi ile birlikte okumaya başlanır.

2. Eğer okuma birlikte yapılıyorsa yetişkin metni sesli olarak cümle cümle okur. Çocuk ise daha düşük bir tonla metni tekrar eder. Eğer okuma yalnız yapılıyorsa eşli okumayı yaptıran çocuğu takip eder ve müdahale edilmesi gereken durumlarda parmağıyla işaret etmek suretiyle ona yön verir.

3. Yetişkin okuma sırasında hatalı gördüğ̈̈ yerleri tekrar okutarak okuyanın hatalarını gidermeye çalışır.

4. Eşli okuma sürecinde okuma yaptıran eş, okuyanı olumlu yönde motive eder.

5. Çocuk okumayı kendisi yaparsa, yetişkin okuyucunun (çocuk, öğrenci vs.) atladığı satır, kelime ya da tereddüt ettiği sözcüklerde ona yardımcı olur.

6. Okuma sürecinde okuyana teşvik için çıkartmalar, rozetler veya başka hediyeler verilerek ödüllendirilir. Böylece eşli okuma süreci tamamlanmış olur (Aytan, 2015).

White (2014), eşli okuma yönteminin uygulanmasını okuma öncesi, okuma anı ve okuma sonrası olmak üzere üç bölüme ayırmaktadır.

Okuma öncesinde yapılması gerekenler:

$\checkmark \quad$ Seviyeye uygun kitap seçiminin yapılması,

$\checkmark$ Seçilen kitabın okunması zor olmayan, akıcı bir kitap olması,

Okuma anında yapılması gerekenler:

$\checkmark$ Metnin çocuk ve yardımcı tarafından sesli olarak okunması

$\checkmark$ Okumanın akıcı olmasına özen gösterilmesi

$\checkmark \quad$ Metinde anlatılanlarla gerçek yaşam arasında bağlantı kurulması

Okuma sonrası yapılması gerekenler:

$\checkmark$ Çocukla birlikte metin hakkında tartışılması,

$\checkmark$ Sorularla okumanın pekiştirilmesi

Eşli okuma yönteminin okuyucunun kelimeleri doğru tanımasına, okuma hızının gelişmesine, kendine güven duymasına, okumaya karşı güdülenmesine, okurken yazım kurallarına dikkat etmesine ve okumaktan haz almasına katkı sağlayacağı vurgulanmıştır (Zutell ve Rasinski, 1991). Bunun yanında (Koskinen ve Blum, 1986) eşli okuma yönteminin uygulandığı sınıflarda öğrencilerin kelime algısı, okumada akıcılık ve okuduğunu anlama düzeylerinde gelişmelerin olduğunu ifade etmişlerdir.

Okuma güçlüğü konusunda yapılan araştırmalar incelendiğinde ülkemizde özellikle ilköğretim çağındaki çoğu çocukta okuma güçlüğünün olduğu görülmektedir. Çocuklara okuma alışkanlığının kazandırılması için bu tür çocukların okuma güçlüklerinin tedavi edilmesi gerekmektedir. Günümüzde artık okullarda öğretmenler bilgi aktaran değil, bilgiye ulaşması için öğrenciyi yönlendiren kişi konumuna gelmiştir. Yeni anlayışla birlikte öğrencilerden, araştıran ve araştırmalarının sonunda bir takım bilgilere ulaşan, ulaştığı bilgilerle eski bilgilerini harmanlayan ve nihai sonuçlara ulaşan bireyler olmaları beklenmektedir. Bir öğrencinin bu gibi becerileri yerine getirebilmesi için akıcı okuma ve okuduğunu anlama becerilerine sahip olması kaçınılmazdır. Bu bakımda araştırmada okuma güçlüklerini gidermede eşli okuma yönteminin etkisi incelenmiştir.

\section{Araştırmanın Amacı}

Araştırmanın amacı okuma güçlüğü yaşayan 5. sınıf öğrencisinin okuma becerisini geliştirmede eşli okuma yönteminin etkisini incelemektir. Araştırmada bu genel amaca ulaşmak için şu sorulara cevap aranmıştır:

1. 5. sınıf öğrencilerinin okuma seviyeleri nasıldır?

2. 5. sınıf öğrencilerinin okuma seviyelerini geliştirmede eşli okuma yönteminin etkisi nedir?

\section{Yöntem}

\section{Araştırmanın Modeli}

Araştırmada nitel araştırma desenlerinden, eylem araştırması yöntemi kullanılmıştır. Eylem araştırması, bir okulda çalışan yönetici, öğretmen, eğitim uzmanı veya diğer tür kuruluşlarda çalışan mühendis, yönetici, planlamacı, insan kaynakları uzmanı gibi bizzat uygulamanın içinde olan kişiler tarafından uygulanır. Uygulayıcının doğrudan kendisinin ya da bir araştırmacı ile birlikte gerçekleştirdiği ve uygulama sürecine ilişkin 
sorunların ortaya çıkarılması ya da hali hazırda ortaya çıkmış bir sorunu anlama ve çözmeye yönelik veri toplama ve analiz etmeyi içeren bir araştırma yaklaşımıdır (Yıldırım ve Şimşek, 2005).

\section{Katılımcıların Seçimi}

Araştırma Bartın Merkez Gazi Ortaokulu 5. sınıfta okuma güçlüğü çeken bir öğrenci üzerinde yapılmıştır. Deneklerin seçiminde 5. sınıf öğretmenleriyle iletişime geçilmiş ve onlara 5. sınıf düzeyinde okuma güçlügü çeken öğrencilerinin olup olmadığını sorulmuştur. 5. sınıfta okuma güçlüğü çektiği düşünülen 4 öğrenci belirlenmiştir. Araştırmacı bu öğrencilere kendi sınıf düzeylerinde metinler okutmuş ve okuma düzeylerini belirlemeye çalışmıştır. Bu öğrenciler arasından araştırmanın amacına uygun olarak 1 öğrenci belirlemiştir.

\section{Veri Toplama Araçları}

Veri toplama aracı olarak Milli Eğitim Bakanlığı Talim Terbiye Kurulu Başkanlığı tarafindan onaylı 3. 4. ve 5. sınıf Türkçe ders kitapları kullanılmıştır. Eşli okuma yöntemiyle yapılan uygulama 3. sınıf Türkçe ders kitabından seçilen hikâye türü 30 metinle yürütülmüştür. Ayrıca öğrenciye ev ödevi olarak okuması için 30 masal kitabı verilmiştir. Verilerin değerlendirilmesinde hata analizi envanteri kullanılmıştır. Bu envanter Yılmaz (2006) tarafından Türkçeye uyarlanmıştır. Bu envanter ortam ölçeği, seslendirme ölçeği ve soru ölçeği olmak üzere 3 bölümden oluşmaktadır. Hata analiz envanteri değerlendirme ölçütleri aşağıda verilmiştir:

\section{Hata Analiz Envanteri}

a) Ortam Ölçeği Ölçütleri

Hiç okuyamadi $=0$ puan

Sözcüğü öğretmen verdi $=1$ puan

Aynı sözcükleri, yapıları içermedi $=2$ puan

Aynı sözcükleri, yapıları içerdi $=3$ puan

Aynı sözcükleri, yapıları içerdi; kendi koyduğu sözcükler yazarla aynı ifadede $=4$ puan

Kendi kendini düzeltti $=5$ puan

b) Seslendirme Ölçeği Ölçütleri

Kendi koyduğu sözcükle harf benzerliği yok $=0$ puan

Kendi koyduğu sözcükle 1 harf benzerliği var $=1$ puan

Kendi koyduğu sözcükle 2 harf benzerliği var $=2$ puan

Kendi koyduğu sözcükle $\mathrm{N}$ harf benzerliği var $=\mathrm{N}$ puan

c) Soru Ölçeği Ölçüitleri

Basit Anlama Soruları İçin;

Hiç cevaplanmayan sorular $=0$ puan

Cevabı kismen verilen sorular $=1$ puan

Tam cevaplanan sorular $=2$ puan

Derinlemesine Anlama Soruları İçin;

Hiç cevap verilmeyen sorular $=0$ puan

Cevabı kısmen verilen sorular $=1$ puan

Doğruya yakın fakat eksik cevaplanan sorular $=2$ puan

Tam cevaplanan sorular $=3$ puan (Yilmaz, 2006).

Hata Analiz Envanteri ile 3 farklı okuma düzeyi belirlenmektedir. Bunlar;

a) Endişe Düzeyi: Bireyin çok sayıda okuma hatası yaptığını ve okuduğunun çok azını anladığını gösterir. Seslendirme, ortam ve soru ölçeklerinden alınan toplam puan 180'in altında ise bu öğrenci endişe düzeyindedir.

b) Öğretim Düzeyi: Bireyin istenilen şekilde okuması ve anlaması için bir öğretmen veya bir yetişkinin desteğine ihtiyaç duyduğunu ifade eder. Seslendirme, ortam ve soru ölçeklerinden alınan toplam puan 180 veya bunun üstünde bir sayı ise öğrenci öğretim düzeyindedir.

c) Serbest Düzey: Bireyin öğretmen veya bir yetişkinin yardımına ihtiyaç duymadan, düzeyine uygun materyalleri okuması ve anlamasını ifade eder. Seslendirme, ortam ve soru ölçeğinden alınan toplam puan 240 ve bunun üzerinde bir sayı ise öğrenci serbest düzeydedir (Yılmaz, 2006).

\section{Verilerin Toplanması}

Öğrencinin kelime tanıma ve anlama düzeyini belirlemek için önce 5. sınıf Türkçe ders kitabından "Çöpler ve Geri Dönüşüm” adlı bilgilendirici metin okutulmuştur. Kelime tanıma ve anlama düzeyi "Hata Analizi 
Envanteri"ne göre analiz edilmiş, öğrencinin okuma seviyesinin endişe düzeyinde olduğu görülmüştür. Ardından 4. sınıf Türkçe ders kitabından "Gezgin Kaplumbağa Denizli’de” adlı bilgilendirici metin okutulmuştur. Aynı şekilde kelime tanıma ve anlama düzeyi "Hata Analizi Envanteri”yle belirlendikten sonra öğrencinin okuma seviyesinin yine endişe düzeyinde olduğu görülmüştür. Daha sonra öğrenciye 3. sınıf Türkçe ders kitabından "Trafik Kuralları" adı bilgilendirici metin okutulmuş ve öğrencinin kelime tanıma ve anlama düzeyi "Hata Analizi Envanteri” yle belirlenmiş ve öğrencinin okuma seviyesinin öğretim düzeyinde olduğu tespit edilmiştir. Eşli okuma yöntemiyle uygulamaya 3. sınıf ders kitabından seçilen metinlerle yapılmaya karar verilmiştir.

Uygulama okulda müdür yardımcısının odasında bireysel olarak yapılmıştır. Uygulama haftada 5 saat (her gün bir saat) olmak üzere 30 saat devam etmiştir. Uygulamada her bir metinle ilgili öğrenciye 3 basit anlama ve 3 derinlemesine anlama olmak üzere toplam 6 soru sorulmuştur. Okuma eğitiminin sonunda öğrenciye 3. sınıf Türkçe ders kitabından seçilen "Yerli Malı" isimli metin okutulmuştur. Öğrencilerin okuma seviyelerini tam olarak belirlemek için değerlendirme metinleri, bilgilendirici metin türünden seçilmiştir.

\section{Verilerin Analizi}

Verilerin analizinde hata analizi envanteri kullanılmıştır. Öğrencinin okumasının ses kaydı alınmıştır. Bu kayıtlar hata analizi envanterine göre analiz edilmiştir. Ayrıca her bir metinle ilgili 6 adet okuduğunu anlama sorusu sorulmuştur.

\section{Bulgular}

\section{Öğrencinin Uygulama Öncesi Okuma Seviyesi}

Eşli okuma yöntemiyle okuma uygulamalarına başlamadan önce öğrencinin uygulama öncesi durumu tespit edilmiştir. Öğrencinin okuması kayıt altına alınmış, okunan metinle ilgili sorulan sorularla, okuma seviyesi belirlenmiştir. Öğrenciye 5. sınıf Türkçe ders kitabından "Çöpler ve Geri Dönüşüm”, 4. sınıf Türkçe ders kitabından "Gezgin Kaplumbağa Denizli'de” ve 3. Sınıf Türkçe ders kitabından “Trafik Kuralları” isimli metinler okutulmuştur. Öğrencinin okuma seviyesine ilişkin elde edilen bulgular tablolar halinde verilmiştir.

Tablo 1. Öğrencinin Uygulama Öncesi 5. Sınıf Okuma Seviyesi

\begin{tabular}{ll}
\hline Metnin Adı & Çöpler ve Geri Dönüşüm \\
Metnin Türü & Bilgilendirici Metin \\
Metnin Sınıf Düzeyi & 5. Sınıf \\
Metindeki Kelime Sayısı & 385 \\
Yanlış Okunan Kelime Sayısı & 105 \\
Okuma Seviyesi & $\begin{array}{l}\text { Ortam Ölçeği }+ \text { Seslendirme Ölçeği }+ \text { Soru } \\
\text { Ölçeği }=46+79+46=171 \text { puan= Endişe Düzeyi }\end{array}$ \\
\hline
\end{tabular}

Tablo 1 incelendiğinde öğrencinin 385 kelimeden oluşan metni okurken 105 sesli okuma hatası yaptığı ve okuma seviyesinin endişe düzeyinde (171 puan) olduğu görülmektedir.

Tablo 2. Öğrencinin Uygulama Öncesi 4. Sınıf Okuma Seviyesi

\begin{tabular}{ll}
\hline Metnin Adı & $\begin{array}{l}\text { Gezgin Kaplumbağa Denizli’de } \\
\text { Metnin Türü }\end{array}$ \\
Bilgilendirici Metin \\
Metnin Sınıf Düzeyi & 4. Sınıf \\
Metindeki Kelime Sayısı & 263 \\
Yanlış Okunan Kelime Sayısı & 84 \\
Okuma Seviyesi & $\begin{array}{l}\text { Ortam Ölçeği }+ \text { Seslendirme Ölçeği }+ \text { Soru } \\
\text { Ölçeği }=50+81+46=177 \text { puan= Endişe Düzeyi }\end{array}$ \\
\hline
\end{tabular}


Tablo 2 incelendiğinde öğrencinin 263 kelimeden oluşan metni okurken 84 sesli okuma hatası yaptı̆̆1 ve okuma seviyesinin endişe düzeyinde (177 puan) olduğu görülmektedir.

Tablo 3. Öğrencinin Uygulama Öncesi 3. Sınıf Okuma Seviyesi

\begin{tabular}{ll}
\hline $\begin{array}{l}\text { Metnin Adı } \\
\text { Metnin Türü }\end{array}$ & $\begin{array}{l}\text { Trafik Kuralları } \\
\text { Bilgilendirici Metin }\end{array}$ \\
Metnin Sınıf Düzeyi & 3. Sınıf \\
$\begin{array}{l}\text { Metindeki Kelime Sayısı } \\
\text { Yanış Okunan Kelime Sayısı }\end{array}$ & 42 \\
Okuma Düzeyi & $\begin{array}{l}\text { Ortam Ölçeği }+ \text { Seslendirme Ölçeği }+ \text { Soru } \\
\text { Ölçeği }=62+72+56=190 \text { puan }=\text { Öğretim Düzeyi }\end{array}$ \\
\hline
\end{tabular}

Tablo 3 incelendiğinde öğrencinin 134 kelimeden oluşan metni okurken 42 sesli okuma hatası yaptığı ve okuma seviyesinin öğretim düzeyinde (190 puan) olduğu görülmektedir.

Öğrencinin Uygulama Sonrası Okuma Seviyesi

Öğrenciye uygulama sonunda 3. sınıf Türkçe ders kitabından seçilen "Yerli Malı" isimli metin okutulmuştur. Elde edilen bulgular tablo 4'te verilmiştir.

Tablo 4. Öğrencinin Uygulama Sonrası 3. Sınıf Okuma Seviyesi

\begin{tabular}{ll}
\hline $\begin{array}{l}\text { Metnin Adı } \\
\text { Metnin Türüi }\end{array}$ & $\begin{array}{l}\text { Yerli Malı } \\
\text { Bilgilendirici Metin }\end{array}$ \\
Metnin Sınıf Düzeyi & 3. Sınıf \\
Metindeki Kelime Sayısı & 168 \\
Yanlış Okunan Kelime Sayısı & 19 \\
Okuma Düzeyi & $\begin{array}{l}\text { Ortam Ölçeği }+ \text { Seslendirme Ölçeği }+ \text { Soru } \\
\text { Ölçeği } 78+90+73=241 \text { puan= Serbest Düzey }\end{array}$ \\
\hline
\end{tabular}

Tablo 4 incelendiğinde öğrencinin 168 kelimeden oluşan metni okurken 19 sesli okuma hatası yaptığ ve okuma seviyesinin bağımsız düzeyde (241 puan) olduğu görülmektedir.

\section{Tartışma ve Sonuç}

Araştırma sonucunda eşli okuma yönteminin ortaokul 5. sınıf öğrencilerinin sesli okuma hatalarını azaltmada ve okuma seviyelerini yükseltmede etkili olduğu görülmüştür. Elde edilen bu sonuç önceki araştırma sonuçlarıyla benzerlik göstermektedir. Eldredge ve Quinn (1988), Akyol ve Kodan (2016), Yamaç (2013), Fidan ve Akyol (2011), İşler ve Şahin (2016) Ellis (2009) da yaptıkları araştırmada eşli okuma yönteminin sesli okuma hatalarını azalttığı, okuduğunu anlama becerilerini geliştirdiği sonucuna ulaşmışlardır. Eşli okuma yöntemi okuma güçlüğü yaşayan birey ile öğretici bireyin metnin cümle cümle tekrar edilmesidir. Bu yönüyle eşli okumanın temelinde doğrunun tekrar edilmesi yer almaktadır. Bu tekrar işi, okuma güçlüğü çeken birey akıcı okumaya ulaşıncaya kadar devam etmektedir. Bu yönüyle eşli yapılan okumaların okuma güçlüklerini gidermede etkili olduğu söylenebilir. Bu konuda yapılmış araştırmalar bunu destekler niteliktedir. Yılmaz ve Köksal (2008), Y1lmaz (2009), Y1lmaz (2010), Samuels, (1979); Herman, (1985); Rashotte ve Torgesen, (1985); Dowhower,(1987); Sindelar, Monda ve O'Shea, (1990); Young, Bower ve MacKinnon, (1996) yaptıkları araştırmada tekrarlı okuma yönteminin okuma güçlüğü yaşayan çocukların okuma ve okuduğunu anlama becerilerini geliştirdiğini ifade etmişlerdir. Bu açıdan bakıldığında okuma güçlüklerinin giderilmesi kelimelerin ve cümlelerin doğru bir şekilde tekrar edilmesiyle sağlanmaktadır denilebilir. Çünkü gerek eşli okuma yöntemi gerekse okuma güçlüklerini gidermede kullanılan diğer tüm yöntemlerde öğretici bireyin, okuma güçlüğü çeken bireye kelimeleri ya da cümleleri tekrar etmesi söz konusudur. 


\section{References}

Akyol, H. ve Kodan, H. (2016). Okuma güçlügünün giderilmesine yönelik bir uygulama: Akıc1 okuma stratejilerinin kullanımı. Ondokuzmayı Üniversitesi Ĕ̈itim Fakültesi Dergisi, 35(2), 7-21.

Aytan, N. (2015). Eşli okuma ve uygulama süreci. International Journal of Social Science Studies, 32, 527-536.

Dökmen, Ü. (1994). Okuma becerisi ilgisi ve alışkanlı̆̆ üzerine psiko-sosyal bir araştırma. Ankara: MEB Yayınevi.

Dowhower, S. L. (1987). Effects of repeated reading on second grade transitional readers fluency and comprehension. Reading Research Quarterly, 22(4) 389-406.

Eldredge, J. L., and Quinn, D. W. (1988). Increasing reading performance of low-achieving second graders with dyad reading groups. Journal of Educational Research, 82(1), 40- 46.

Ellis, W. A. (2009). The Impact of C-PEC (choral reading, partner reading, echo reading and performance of text) on third grade fluency and comprehension development. (Doctoral Dissertation). University of Memphis.

Fidan, N. K. ve Akyol, H. (2011). Hafif düzeyde zihinsel öğrenme güçlüğü olan bir öğrencinin okuma ve anlama becerilerini geliştirmeye yönelik nitel bir çalışma. Kuramsal Eğitim Bilim Dergisi, 4(2), 16-29.

Herman, P. A. (1985). The effect of repeated readings on reading rate speech pauses and word recognition. Reading Research Quarterly, 20(5), 553-565.

İşler, N. K. ve Şahin. A. E. (2016). Bir ilkokul 4. sınıf öğrencisinin okuma bozukluğu ve anlama güçlüğü: Bir durum çalışması, Ana Dili Eğitimi Dergisi, 4(2), 174-186.

Joshi, M., Dahlgren, M. and Gooden, R. B. (2002). Teaching reading in an inner city school through a multisensory teaching approach. Annals of Dyslexsia, (52), 229-242.

Kee, P. Mc. (1958). İlkokulda okuma öğretimi II. (Çev. M. Şükrü Koç). İstanbul: Maarif Basımevi.

Koskinen, P. S., and Blum, I.H. (1986). Paired repeated reading: A classroom strategy for developing fluent reading. Reading Teacher, 40(1), 70-75.

May, F. B. (1986). Reading as communication: An interactive approach. USA: Merril Publishing Company.

Morgan, R. (1986). Helping children read: The paired reading handbook. London: Methuen.

Rashotte, C. A. and Torgesen, J. K. (1985). Repeated readings and reading fluency in learning disabled chiledren. Reading Research Quarterly , (20), 180-188.

Salinger, T. (2003). Helping older struggling readers. Preventing School Failure, 47, 79-85.

Samuels, S. J. (1979). The method of repeated reading. The Reading Teacher, (32),403-408.

Sinderal, P. T., Monda, L. E. and O’Shea, L. J. (1990). Effects of repeated readings on instructional and mastery level readers. Juornal Of Educational Research, 83(4), 220-226.

Topping, K. (1998). Effective tutoring in America reads: E reply to wasik. The Reading Teacher, 52, 42-50.

White, J. (2014). Louisiana department of education (LDOE). ABD: Mississippi.

Yamaç, A. (2013). İlkokul dördüncü sınıf düzeyinde bir öğrencinin sesli okuma akıcılığını artırmaya yönelik bir uygulama. K. Ü. Kastamonu Ĕ̈itim Dergisi, 23(2), 631-644.

Yıldırım, A., Şimşek, H. (2005). Sosyal bilimlerde nitel araştırma yöntemleri. Ankara: Seçkin Yayıncılık.

Yılmaz, M. (2006). İlköğretim 3. sınıf öğrencilerinin sesli okuma hatalarını düzeltmede ve okuduğunu anlama becerilerini geliştirmede tekrarlı okuma yönteminin etkisi. (Yayınlanmamış Doktora Tezi). Gazi Üniversitesi Eğitim Bilimleri Enstitüsü, Ankara.

Yılmaz, M. (2008). Kelime tekrar tekniğinin akıcı okuma becerilerini geliştirmeye etkisi. Türk Ĕ̈itim Bilimleri Dergisi, 6, 323-350.

Yılmaz, M. ve Köksal, K. (2008). Tekrarlı okuma yönteminin okuduğunu anlamaya etkisi. Milli Eğitim Dergisi, 179, 51-65.

Yılmaz, M. (2009). Sesli okuma hatalarının tekrarlı okuma yöntemiyle düzeltilmesi. Milli Ĕ̆itim Dergisi, 183, 1941.

Yılmaz, M. (2018). Okuma Eğitimi. Muamber Yılmaz (Ed.), Yeni gelişmeler ışı̆̆ında Türkçe öğretimi içinde (s. 81-112). Ankara: Pegem Akademi Yayınlar1.

Y1lmaz, M. (2011). The effect of some factors on elementary education third grade students' reading achievements and these achievements. Energy Education Science and Technology Part B: Social and Educational Studies, 3(4), 713-724.

Yılmaz, M. (2010). Okuma güçlüklerinin tekrarlı okuma yöntemiyle giderilmesine yönelik bir meta analiz çalışması. Intenational Conference on New Horizons in Education. Gazimağusa, Kuzey Kıbrıs Türk Cumhuriyeti, p. 647-653. 
Young, A. R., Bowers, P. G. and Mackinnon, G. E. (1996). Effects of prosodic modeling and repeated reading on poor readers fluency and comprehension. Applied Psycholinguistics, 17(1), 59-84.

Zutell, J. \& Rasinski, T.V. (1991). Training teachers to attend to their students oral reading fluency. Theory Into Practice, 30, 211-217. 